\title{
A Survey for Escherichia coli Virulence Factors in Asymptomatic Free-Ranging Parrots
}

\author{
André Becker Saidenberg,, ${ }^{1}$ Neiva Maria Robaldo Guedes, ${ }^{2}$ Gláucia Helena Fernandes Seixas, ${ }^{3}$ \\ Mariangela da Costa Allgayer, ${ }^{4}$ Erica Pacífico de Assis, ${ }^{5}$ Luis Fabio Silveira, ${ }^{5}$ \\ Priscilla Anne Melville, ${ }^{1}$ and Nilson Roberti Benites ${ }^{1}$ \\ ${ }^{1}$ Departamento de Medicina Veterinária Preventiva e Saúde Animal, Faculdade de Medicina Veterinária e Zootecnia, \\ Universidade de São Paulo, 05508270 São Paulo, SP, Brazil \\ ${ }^{2}$ Programa de MDR, Universidade Anhanguera-UNIDERP, and Projeto Arara-azul, 79051660 Campo Grande, MS, Brazil \\ ${ }^{3}$ Projeto Papagaio-verdadeiro, Fundação Neotrópica do Brasil, 79290000 Bonito, MS, Brazil \\ ${ }^{4}$ Universidade Luterana do Brasil, 92425900 Canoas, RS, Brazil \\ ${ }^{5}$ Departamento de Zoologia, Instituto de Biociências, Universidade de São Paulo, 05508090 São Paulo, SP, Brazil
}

Correspondence should be addressed to André Becker Saidenberg, andresaidenberg@usp.br

Received 19 April 2012; Accepted 20 May 2012

Academic Editors: M. H. Kogut and A. Pratelli

Copyright (C) 2012 André Becker Saidenberg et al. This is an open access article distributed under the Creative Commons Attribution License, which permits unrestricted use, distribution, and reproduction in any medium, provided the original work is properly cited.

\begin{abstract}
Parrots in captivity are frequently affected by Escherichia coli (E. coli) infections. The objective of this study was to collect information on the carrier state for E. coli pathotypes in asymptomatic free-ranging parrots. Cloacal swabs were collected from nestlings of Hyacinth, Lear's macaws and Blue-fronted Amazon parrots and tested by polymerase chain reaction (PCR) for virulence factors commonly found in enteropathogenic, avian pathogenic, and uropathogenic E. coli strains. In total, 44 samples were cultured and E. coli isolates were yielded, from which DNA was extracted and processed by PCR. Genes commonly found in APEC isolates from Blue-fronted Amazon parrots and Hyacinth macaws were expressed in 14 of these 44 samples. One atypical EPEC isolate was obtained from a sample from Lear's macaw. The most commonly found gene was the increased serum survival (iss) gene. This is the first report, that describes such pathotypes in asymptomatic free-living parrots. The findings of this study suggest the presence of a stable host/parasite relationship at the time of the sampling brings a new understanding to the role that E. coli plays in captive and wild parrots. Such information can be used to improve husbandry protocols as well as help conservation efforts of free-living populations.
\end{abstract}

\section{Introduction}

Parrots are among the most endangered group of birds worldwide, and 15 of the 84 Brazilian species are classified as being vulnerable or critically endangered [1]. Studies on parrot populations are important to establish a database that can be assessed in the event of outbreaks, which could also be useful for subsequent epidemiological studies and conservation efforts [2]. However, health surveys of freeranging wild animals are mostly focused on retrospective studies on mortality $[3,4]$. Research on diseases affecting free-ranging parrots is still scarce and studies performed often fail to maximize the scientific information that could be gathered $[2,5-8]$. Such data could be of extreme importance in guiding conservation measures ex situ and in situ.

The Hyacinth macaw and Lear's macaw are well-known flagship species that have suffered heavily owing to the destruction of habitat and illegal trade. A number of studies aimed at promoting their recovery have been performed and actions taken; however, they are still classified as endangered species and face severe threats to their longterm survival [9]. On the other hand, the Blue-fronted Amazon parrot is rated as a species of least concern regarding its conservation status [9]. It is, however, the most illegally traded parrot species in Brazil, and therefore, it is possible that decades of successive capturing of nestlings and 
TABLE 1: Cloacal swab samples from free-ranging parrot nestlings tested for select Escherichia coli virulence factors. Surveyed species and the number of positive samples for each tested gene/association by polymerase chain reaction (PCR) are shown.

\begin{tabular}{|c|c|c|c|c|c|c|c|c|c|c|}
\hline Species & Number of positive samples/total number of samples & eae & $b f p$ & $s f a$ & pap & iss & $i u c$ & tsh & HlyA & cnfl \\
\hline Amazona aestiva & $7 / 21$ & - & - & - & - & + & - & - & - & - \\
\hline Amazona aestiva & $1 / 21$ & - & - & + & - & + & - & - & - & - \\
\hline Amazona aestiva & $1 / 21$ & - & - & - & - & + & - & + & - & - \\
\hline Amazona aestiva & $1 / 21$ & - & - & - & - & + & + & - & - & - \\
\hline Amazona aestiva & $1 / 21$ & - & - & + & - & + & - & - & - & + \\
\hline Anodorhynchus hyacinthinus & $3 / 10$ & - & - & - & - & + & - & - & - & - \\
\hline Anodorhynchus leari & $1 / 13$ & + & - & - & - & - & - & - & - & - \\
\hline
\end{tabular}

concomitant ageing of the adult population could cause local extinctions in several areas where it is still common today [10].

Studies have established that the intestinal flora of most species of healthy captive psittacines is composed essentially of Gram-positive bacteria [11,12]. Parrots in captivity are frequently affected by infections caused by Gram-negative bacteria, and these microorganisms are considered either pathogenic or opportunistic [13]. One such bacterium, Escherichia coli (E. coli), is frequently involved in respiratory, digestive, and septicemic disorders in captive parrots [13]. It is possible to classify E. coli into pathotypes by using genes responsible for the expression of virulence factors. Commonly described pathotypes include EPEC (enteropathogenic E. coli), APEC (avian pathogenic E. coli), and UPEC (uropathogenic E. coli) [14, 15]. EPEC is an important category of diarrheagenic E. coli and a major cause of infant diarrhea in developing countries, while APEC is recognized for significant economic losses to the poultry industry, resulting in respiratory diseases and septicemia [14, 15]. UPEC is a serious cause of urinary diseases in humans, causing cystitis that may progress to pyelonephritis [16]. Although, certain $E$. coli classification studies performed on wild birds [17-22] and those involving captive psittacines have found a certain degree of correlation between disease and specific pathotypes [23-25], current serological methods to determine the pathogenicity of E. coli strains do not accurately predict which strains will be pathogenic in which birds [13].

The purpose of this study was to test cloacal samples from asymptomatic free-living nestlings (Blue-fronted Amazon parrots as well as Hyacinth and Lear's macaws) to determine if they could be carriers of recognized E. coli pathotypes. In addition, we discuss the role that these strains could play in both free-living and captive parrots.

\section{Materials and Methods}

2.1. Microbiological Examination. The samples of this study were collected during field surveys of the nestlings of Hyacinth macaws and Blue-fronted Amazon parrots in the Pantanal (wetlands) region of the Refúgio Ecológico Caiman and neighboring farms $\left(19^{\circ} 58^{\prime} \mathrm{S}, 56^{\circ} 24^{\prime} \mathrm{W}\right)$ in Mato Grosso do Sul State, and of Lear's macaws at the Estação Ecológica de Canudos $\left(09^{\circ} 53^{\prime} 48^{\prime \prime} \mathrm{S}, 39^{\circ} 01^{\prime} 35^{\prime \prime} \mathrm{W}\right)$ in the Caatinga (semiarid) of the Bahia State. Cloacal swabs (CultureSwab Sterile,
DIFCO Becton Dickenson and Company, Sparks, Maryland, USA) were moistened with care using a sterile saline solution so as not to contaminate the swab during insertion in the cloaca. All chicks had no evident signs of disease (soiled vent, emaciation, prostration, or delays in development according to their estimated age). In total, 44 samples were obtained, of which 10 were from Hyacinths, 13 from Lear's, and 21 from Blue-fronted Amazon parrots.

The swabs were refrigerated up to processing at which point they were aerobically incubated in BHI broth (Brain Heart Infusion, DIFCO) for 24 hours at $37^{\circ} \mathrm{C}$. They were then streaked onto MacConkey (DIFCO) agar plates and incubated for another 24 hours at $37^{\circ} \mathrm{C}$. Bacteria were identified using a specific enterobacteria identification kit (Newprov, Pinhais, Paraná, Brazil) and stored at $-20^{\circ} \mathrm{C}$. Isolates were tested using polymerase chain reaction (PCR) (Table 2.), for the presence of E. coli attaching and effacing (eae) gene and bundle-forming pili structural $(b f p A)$ gene of EPEC [26]. For APEC, the aerobactin (iucD), cytotoxic necrotizing factor ( $c n f 1), \mathrm{S}$ fimbrial adhesin (sfa), and $\mathrm{P}$ fimbrial adhesin ( $p a p \mathrm{EF}$ ) genes were amplified. UPEC utilized alpha hemolysin $(H l y \mathrm{~A})$ in addition to the genes used for APEC [27]. Additional APEC genes for serum resistance (iss) and temperature-sensitive hemagglutinin ( $t s h$ ) were also tested [28].

\section{Results}

E. coli was obtained from all 44 samples. Details on the positive samples are given in Table 1 . One sample was positive solely for eae and not for $b f p$ and was characterized as atypical EPEC. This sample was collected from a Lear's macaw chick. A large number of samples were positive for virulence factors commonly found in APEC (14 samples), with most originating from Blue-fronted Amazon chicks. The gene most frequently found was iss (14 positive samples). This gene was also found associated with other virulence factors in 4 samples, all from Blue-fronted Amazon parrots. There was also an association between other virulence factors among some isolates (Table 1).

\section{Discussion}

EPEC have the ability to cause lesions on the intestinal mucosa, leading to severe diarrhea. This process is initiated by adherence to the epithelial cell membrane and is mediated 
TABLE 2: Virulence factors and gene sequences tested by polymerase chain reaction (PCR) according to the described references.

\begin{tabular}{|c|c|c|}
\hline Virulence factor & Sequence $\left(5^{\prime}-3^{\prime}\right)$ & Reference \\
\hline \multirow{2}{*}{ Intimin $(e a e)$} & F-CTGAACGGCGATTACGCGAA & Aranda et al. [26] \\
\hline & R-CGAGACGATACGATCCAG & \multirow{2}{*}{ Aranda et al. [26] } \\
\hline \multirow{2}{*}{ Bundle forming pili ( $b f p$ ) } & F-AATGGTGCTTGCGCTTGCTGC & \\
\hline & R-GCCGCTTTATCCAACCTGGTA & \multirow{2}{*}{ Yamamoto et al. [27] } \\
\hline \multirow{2}{*}{ S fimbrial adhesin (sfa) } & F-CTCCGGAGAACTGGGTGCATCTTAC & \\
\hline & R-CGGAGGAGTAAT TACAAACCT GGCA & \multirow{2}{*}{ Yamamoto et al. [27] } \\
\hline \multirow{2}{*}{ P fimbrial adhesin (pap) } & F-GCAACAGCAACGCTGGTTGCATCAT & \\
\hline & R-AGAGAGAGCCACTCTTATACGGACA & \multirow{2}{*}{ Ewers et al. [28] } \\
\hline \multirow{2}{*}{ Increased serum survival (iss) } & F-AGAGAGAGCCACTCTTATACGGACA & \\
\hline & R-CTATTGTGAGCAATATACA & \multirow{2}{*}{ Yamamoto et al. [27] } \\
\hline \multirow{2}{*}{ Aerobactin (iuc) } & F-TACCGGATTGTCATATGCAGACCGT & \\
\hline & R-AATATCTTCCTCCAGTCCGGAGAAG & \multirow{2}{*}{ Ewers et al. [28] } \\
\hline \multirow{2}{*}{ Temperature-sensitive hemagglutinin (tsh) } & F-ACTATTCTCTGCAGGAAGTC & \\
\hline & R-CTTCCGATGTTCTGAACGT & \multirow{2}{*}{ Yamamoto et al. [27] } \\
\hline \multirow{2}{*}{ Alpha hemolysin (hlyA) } & F-AACAAGGATAAGCACTGTTCTGGCT & \\
\hline & R-ACCATATAAGCGGTCATTCCCGTCA & \multirow{3}{*}{ Yamamoto et al. [27] } \\
\hline \multirow{2}{*}{ Cytotoxic necrotizing factor (cnf1) } & F-AAGATGGAGTTTCCTATGCAGGAG & \\
\hline & R-CATTCAGAGTCCTGCCCTCATTATT & \\
\hline
\end{tabular}

by the adhesin intimin (encoded by the eae gene) [14]. Typical EPEC strains possess both intimin and bundleforming pili (encoded by the $b f p$ gene), which are responsible for the initial contact between the bacteria and the host cell; atypical isolates, on the other hand, lack the bfp gene [29]. Humans are considered the primary reservoir for the typical pathotype although it has also been found in dogs and cats $[29,30]$.

One of the samples in this study was characterized as an atypical EPEC. These strains are frequently isolated from domestic animals. There are few reports of the presence of atypical EPEC in birds, especially the isolates obtained from poultry [30-32]. There are also reports of atypical EPEC causing fatal outbreaks in backyard passerine species [18], and carriers have been found among feral pigeons and rehabilitated seagulls $[20,22]$. A study using 103 samples from captive psittacines detected 4 samples characterized as typical EPEC and 3 others as atypical isolates, all of which originated from clinical cases of diarrhea, enteritis, or septicemia [23]. Another survey conducted in Brazil regarding necropsy cases of symptomatic parrots also showed the presence of the eae gene in 2 atypical samples of $E$. coli isolated from the livers of 2 individual pet Amazon parrots [24]. The fact that we found an atypical isolate in an asymptomatic bird, especially a free-ranging individual, suggests that this pathotype is not pathogenic in all parrots depending on the situation to which the birds are subjected.

APEC and UPEC share several genes that encode virulence factors such as $\mathrm{P}$ fimbrial adhesin (pap gene) and $\mathrm{S}$ fimbrial adhesin (sfa gene) [33]. These genes allow UPEC to bind and invade host cells and tissues [34]. APEC has been extensively studied in poultry where it has been observed that the $\mathrm{P}$ fimbrial adhesion enables binding of bacteria to internal organs and protects against heterophilic inflammation [35], while the S fimbrial adhesin is associated with omphalitis, salpingitis, chronic respiratory diseases, and sepsis [36]. Although several virulence factors have been associated with clinical cases of APEC in poultry, no specific factor has been confirmed to be responsible for contributing to the pathogenicity observed [37], which makes it difficult to interpret results among lesser-studied groups such as wild birds.

Siderophores, such as aerobactin (iuc gene), enable E. coli to obtain iron stores from the host, and strains with this gene are quite frequently associated with clinical cases of poultry [38]. One sample isolated from a Blue-fronted Amazon was positive for this gene. Toxins, such as alpha hemolysin (hly $\mathrm{A}$ gene-characteristic of UPEC) and cytotoxic necrotizing factor 1 ( $c n f 1$ gene), provide the ability to cause tissue damage, contributing to dissemination and release of host nutrients while impairing the immune defenses [34].

In this investigation, 2 samples were positive for the $s f a$ and 1 was positive for the $c n f 1$ gene. These genes have been reported in pathogenic strains of $E$. coli isolated from septicemic poultry [36], as well as from human and domestic animals with extraintestinal pathogenic E. coli infections [16, 34]. A survey dealing with healthy feral pigeons detected a number of positive cloacal-swab specimens for the cytotoxic necrotizing factor 1 , showing the potential for disease spread by carriers of this species [22].

Other genes such as the tsh (temperature-sensitive hemagglutinin) and the iss (increased serum survival) are reported to be present in APEC strains. The increased serum survival causes sepsis by conferring resistance to the bacteria against the host immune bactericidal defenses [37]. The exact function of $t s h$ is largely unknown, but it has been shown to be involved in mechanisms of adherence to the respiratory tract of poultry [39]. In this study, 6 samples 
were positive for the iss gene. However, it has been shown in poultry that the presence of the iss gene alone may not be sufficient to identify APEC isolates because this gene can also be found in the intestinal microbiota of healthy individuals, and an association with the iuc gene was reported to be necessary for achieving higher levels of virulence [37]. Interestingly, a sample from an asymptomatic Blue-fronted Amazon chick in this study showed an association between the iss and iuc genes.

This research also found 1 positive sample for the iss/tsh association. In domestic turkeys, a relationship between clinical cases of colibacillosis and the presence of iss and tsh has been described [40]. The occurrence of gene associations such as iss/pap, iss/iuc/tsh, and pap/iuc/tsh has previously been reported in $E$. coli isolated from fecal, liver, and blood samples collected during necropsies performed in symptomatic psittacines in Brazil. These results in captive birds demonstrate that there is a connection between the presence of these genes and some clinical cases of colibacillosis as a contributing cause of death whether as primary or opportunistic pathogens [24].

Even though the sample numbers were too small to reach definite conclusions, we observed differences in the presence of virulence factors among the different species. APEC/UPEC genes were found mostly in species that usually nest on trees and live in a tropical climate (at least in this studied area, for the species $A$. hyacinthinus and A. aestiva). EPEC was found in species that nest on limestone cliffs and inhabit semiarid regions (A. leari). Differences among feeding habits, direct or indirect contact with other wild animals, and human activities (interference due to human settlements and domestic animals) could possibly have influenced these results, and thus, these results should be further investigated.

Although previous studies showed that some virulence factors are indeed involved in clinical cases of colibacillosis in psittacines [23-25], this investigation found a number of carriers for virulence factors. These unusual findings focus the attention on the fact that, at least at the time of sampling, there was a stable host/parasite relationship. Unlike wild birds, parrots maintained in captivity are frequently exposed to a number of factors that cause immunosuppression and increase their susceptibility to disease. These include deficient diets, inadequate hygiene, and lack of mental and physical stimuli; all of these are factors that may determine the course of the disease when the animal is exposed to a microorganism [41].

The concept of disease is considered the result of an interactive relationship among the causative agent, the animal, and environmental factors [42], and a multitude of factors act together in order to initiate the disease process. If a factor is not present, it is probable that the organism will be capable of fighting the pathogen without showing overt clinical signs. The nestlings in our study successfully fledged, indicating that although the potential for disease was present, birds living in their natural environment, without the factors induced by captivity, are more likely to remain disease free.

The results presented here are also important for the future conservation of the 2 endangered species ( $A$. hyacinthinus and A. leari) as well as the heavily trafficked
A. aestiva because they could better guide ex situ husbandry practices involved in captive breeding and rehabilitation/relocation programs, besides assisting monitoring of the overall health of the wild population.

In conclusion, to our knowledge, this is the first study that tested $E$. coli virulence factors in wild psittacines. It is also the first to describe $E$. coli carriers in free-ranging parrots, and the results indicate that although the potential to develop disease was present, several factors that are most likely to be found in captivity needed to be involved in triggering disease development. Other studies involving different species as well as a higher number of samples are important to further define the role and risks involved with specific E. coli pathotypes in the case of both wild and captive psittacines.

\section{Acknowledgments}

The authors wish to thank The World Parrot Trust for supporting activities with the Lear's macaw Project. Additional thanks to Fundação O Boticário, Fundação Neotrópica do Brasil, Fundação Biodiversitas, Instituto Arara Azul, Universidade Anhanguera-Uniderp, R. E. Caiman, Fundação Toyota do Brasil, Parrots International, Bradesco capitalização, and other sponsors of the Projeto Arara Azul, Projeto Papagaioverdadeiro e Projeto Arara-de-Lear. This study was funded by FAPESP Grant no. 2010/51015-0 and Grant no. 2011/ 50375-5.

\section{References}

[1] N. Snyder, P. Mcgowan, J. Gilardi, and A. Grajal, "Parrotsstatus survey and conservation action plan 2000-2004," in The World Parrot Trust, N. Snyder, P. Mcgowan, J. Gilardi, and A. Grajal, Eds., pp. 98-151, IUCN, Cambridge, UK, 2000.

[2] E. G. Stone, G. Montiel-Parra, and T. M. Pérez, "A survey of selected parasitic and viral pathogens in four species of Mexican parrots, Amazona autumnalis, Amazona oratrix, Amazona viridigenalis, and Rhynchopsitta pachyrhyncha," Journal of Zoo and Wildlife Medicine, vol. 36, no. 2, pp. 245-249, 2005.

[3] H. McCallum and A. Dobson, "Detecting disease and parasite threats to endangered species and ecosystems," Trends in Ecology and Evolution, vol. 10, no. 5, pp. 190-194, 1995.

[4] M. G. Spalding and D. J. Forrester, "Disease monitoring of free-ranging and released wildlife," Journal of Zoo and Wildlife Medicine, vol. 24, pp. 271-280, 1993.

[5] K. V. Gilardi, L. J. Lowenstine, J. D. Gilardi, and C. A. Munn, "A survey for selected viral, chlamydial, and parasitic diseases in wild dusky-headed parakeets (Aratinga weddellii) and tui parakeets (Brotogeris sanctithomae) in Peru," Journal of wildlife diseases, vol. 31, no. 4, pp. 523-528, 1995.

[6] S. L. Deem, A. J. Noss, R. L. Cuéllar, and W. B. Karesh, "Health evaluation of free-ranging and captive blue-fronted Amazon parrots (Amazona aestiva) in the Gran Chaco, Bolivia," Journal of Zoo and Wildlife Medicine, vol. 36, no. 4, pp. 598-605, 2005.

[7] M. C. Allgayer, N. M. R. Guedes, C. Chiminazzo, M. Cziulik, and T. A. Weimer, "Clinical pathology and parasitologic evaluation of free-living nestlings of the hyacinth Macaw (Anodorhynchus hyacinthinus)," Journal of Wildlife Diseases, vol. 45, no. 4, pp. 972-981, 2009. 
[8] D. L. McDonald, S. Jaensch, G. J. Harrison et al., "Health and nutritional status of wild Australian psittacine birds: an evaluation of plasma and hepatic mineral levels, plasma biochemical values, and fecal microflora," Journal of Avian Medicine and Surgery, vol. 24, no. 4, pp. 288-298, 2010.

[9] Birdlife International, "IUCN Red List for birds," December 2011, http://www.birdlife.org/.

[10] G. H. F. Seixas, "Projeto Papagaio-verdadeiro (Amazona aestiva): Manejo e conservação no Pantanal e Cerrado de Mato Grosso do Sul, Brasil," PUBVET, vol. 1, p. 410, 2007.

[11] R. L. Bangert, B. R. Cho, P. R. Widders, E. H. Stauber, and A. C. Ward, "A survey of aerobic bacteria and fungi in the feces of healthy psittacine birds," Avian Diseases, vol. 32, no. 1, pp. 46-52, 1988.

[12] L. Allegretti, Isolation and Identification of Lactobacillus Spp., Bifidobacterium Spp., Enterococcus Spp., Pediococcus Spp., and Lactococcus Spp. From the Intestinal Microbiota of Blue-Fronted Parrot (Amazona aestiva) [Ph.D. thesis], University of São Paulo, São Paulo, Brazil, 2009.

[13] H. Gerlach, "Bacteria," in Avian Medicine: Principles and Application, B. W. Ritchie, G. J. Harrison, and L. R. Harrison, Eds., pp. 949-983, Wingers Publishing, Lake Worth, Fla, USA, 1994.

[14] J. P. Nataro and J. B. Kaper, "Diarrheagenic Escherichia coli," Clinical Microbiology Reviews, vol. 11, no. 1, pp. 142-201, 1998.

[15] H. J. Barnes, J. P. Vaillancourt, and W. B. Gross, "Colibacillosis," in Diseases of Poultry, Y. M. Saif, H. J. Barnes, J. R. Glisson, A. M. Fadly, L. R. McDougald et al., Eds., pp. 631-656, Iowa State University, Ames, Iowa, USA, 2004.

[16] J. R. Johnson, T. T. O’Bryan, D. A. Low et al., "Evidence of commonality between canine and human extraintestinal pathogenic Escherichia coli strains that express papG allele III," Infection and Immunity, vol. 68, no. 6, pp. 3327-3336, 2000.

[17] G. Dell'Omo, S. Morabito, R. Quondam et al., "Feral pigeons as a source of verocytotoxin-producing Escherichia coli," Veterinary Record, vol. 142, no. 12, pp. 309-310, 1998.

[18] G. Foster, H. M. Ross, T. W. Pennycott, G. F. Hopkins, and I. M. McLaren, "Isolation of Escherichia coli O86:K61 producing cyto-lethal distending toxin from wild birds of the finch family," Letters in Applied Microbiology, vol. 26, no. 6, pp. 395398, 1998.

[19] H. Schmidt, J. Scheef, S. Morabito, A. Caprioli, L. H. Wieler, and H. Karch, "A new Shiga toxin 2 variant (Stx2f) from Escherichia coli isolated from pigeons," Applied and Environmental Microbiology, vol. 66, no. 3, pp. 1205-1208, 2000.

[20] H. Kobayashi, T. Pohjanvirta, and S. Pelkonen, "Prevalence and characteristics of intimin- and Shiga toxin-producing Escherichia coli from gulls, pigeons and broilers in Finland," Journal of Veterinary Medical Science, vol. 64, no. 11, pp. 10711073, 2002.

[21] C. M. Steele, R. N. Brown, and R. G. Botzler, "Prevalences of zoonotic bacteria among seabirds in rehabilitation centers along the Pacific Coast of California and Washington, USA," Journal of Wildlife Diseases, vol. 41, no. 4, pp. 735-744, 2005.

[22] K. Pedersen, L. Clark, W. F. Andelt, and M. D. Salman, "Prevalence of Shiga toxin-producing Escherichia coli and Salmonella enterica in rock pigeons captured in Fort Collins, Colorado," Journal of Wildlife Diseases, vol. 42, no. 1, pp. 4655, 2006.

[23] C. Schremmer, J. E. Lohr, U. Wastlhuber et al., "Enteropathogenic Escherichia coli in Psittaciformes," Avian Pathology, vol. 28, no. 4, pp. 349-354, 1999.
[24] T. Knöbl, S. N. Godoy, E. R. Matushima, M. B. Guimarães, and A. J. P. Ferreira, "Caracterização molecular dos fatores de virulência de estirpes de Escherichia coli isoladas de papagaios com colibacilose aviária," Brazilian Journal of Veterinary Research and Animal Science, vol. 45, pp. 54-60, 2008.

[25] A. B. S. Saidenberg, Detection of Escherichia coli virulence factors isolated from psittacines with varied clinical signs [Ph.D. thesis], University of São Paulo, São Paulo, Brazil, 2009.

[26] K. R. S. Aranda, S. H. Fabbricotti, U. Fagundes-Neto, and I. C. A. Scaletsky, "Single multiplex assay to identify simultaneously enteropathogenic, enteroaggregative, enterotoxigenic, enteroinvasive and Shiga toxin-producing Escherichia coli strains in Brazilian children," FEMS Microbiology Letters, vol. 267, no. 2, pp. 145-150, 2007.

[27] S. Yamamoto, A. Terai, K. Yuri, H. Kurazono, Y. Takeda, and O. Yoshida, "Detection of urovirulence factors in Escherichia coli by multiplex polymerase chain reaction," FEMS Immunology and Medical Microbiology, vol. 12, no. 2, pp. 85-90, 1995.

[28] C. Ewers, T. Janßen, S. Kießling, H. C. Philipp, and L. H. Wieler, "Rapid detection of virulence-associated genes in avian pathogenic Escherichia coli by multiplex polymerase chain reaction," Avian Diseases, vol. 49, no. 2, pp. 269-273, 2005.

[29] L. R. Trabulsi, R. Keller, and T. A. Tardelli Gomes, "Typical and atypical enteropathogenic Escherichia coli," Emerging Infectious Diseases, vol. 8, no. 5, pp. 508-513, 2002.

[30] G. Krause, S. Zimmermann, and L. Beutin, "Investigation of domestic animals and pets as a reservoir for intimin- (eae) gene positive Escherichia coli types," Veterinary Microbiology, vol. 106, no. 1-2, pp. 87-95, 2005.

[31] S. Pakpinyo, D. H. Ley, H. J. Barnes, J. P. Vaillancourt, and J. S. Guy, "Prevalence of enteropathogenic Escherichia coli in naturally occurring cases of poult enteritis-mortality syndrome," Avian Diseases, vol. 46, no. 2, pp. 360-369, 2002.

[32] R. M. La Ragione, W. A. Cooley, D. D. G. Parmar, and H. L. Ainsworth, "Attaching and effacing Escherichia coli 0103: K+:H- in red-legged partridges," Veterinary Record, vol. 155, no. 13, pp. 397-398, 2004.

[33] M. Sussmann, "Escherichia coli and human disease," in Escherichia coli Mechanisms of Virulence, M. Sussmann, Ed., pp. 3-48, Cambridge University Press, Cambridge, UK, 1997.

[34] J. R. Johnson, "Virulence factors in Escherichia coli urinary tract infection," Clinical Microbiology Reviews, vol. 4, no. 1, pp. 80-128, 1991.

[35] T. Janßen, C. Schwarz, P. Preikschat, M. Voss, H. C. Philipp, and L. H. Wieler, "Virulence-associated genes in avian pathogenic Escherichia coli (APEC) isolated from internal organs of poultry having died from colibacillosis," International Journal of Medical Microbiology, vol. 291, no. 5, pp. 371378, 2001.

[36] T. Knöbl, Caracterização Epidemiológica, Molecular E De Virulência De Escherichia coli sfa + Isoladas De Aves [Ph.D. thesis], Preventive Veterinary Medicine Department, University of São Paulo, São Paulo, Brazil, 2005.

[37] K. A. Tivendale, J. L. Allen, C. A. Ginns, B. S. Crabb, and G. F. Browning, "Association of iss and iucA, but not tsh, with plasmid-mediated virulence of avian pathogenic Escherichia coli," Infection and Immunity, vol. 72, no. 11, pp. 6554-6560, 2004.

[38] M. Dho-Moulin and J. M. Fairbrother, "Avian pathogenic Escherichia coli (APEC)," Veterinary Research, vol. 30, no. 2-3, pp. 299-316, 1999.

[39] C. M. Dozois, M. Dho-Moulin, A. Brée, J. M. Fairbrother, C. Desautels, and R. Curtiss, "Relationship between the Tsh autotransporter and pathogenicity of avian Escherichia coli 
and localization and analysis of the tsh genetic region," Infection and Immunity, vol. 68, no. 7, pp. 4145-4154, 2000.

[40] S. F. Altekruse, F. Elvinger, C. DebRoy, F. W. Pierson, J. D. Eifert, and N. Sriranganathan, "Pathogenic and fecal Escherichia coli strains from turkeys in a commercial operation," Avian Diseases, vol. 46, no. 3, pp. 562-569, 2002.

[41] R. D. Ness, "Integrative therapies," in Clinical Avian Medicine, G. J. Harrison and T. L. Lightfoot, Eds., pp. 343-364, Spix, South Palm Beach, Fla, USA, 2006.

[42] G. A. Wobeser, "What is disease," in Essentials of Disease in Wild Animals, G. A. Wobeser, Ed., pp. 11-24, Blackwell, Ames, Iowa, USA, 2005. 

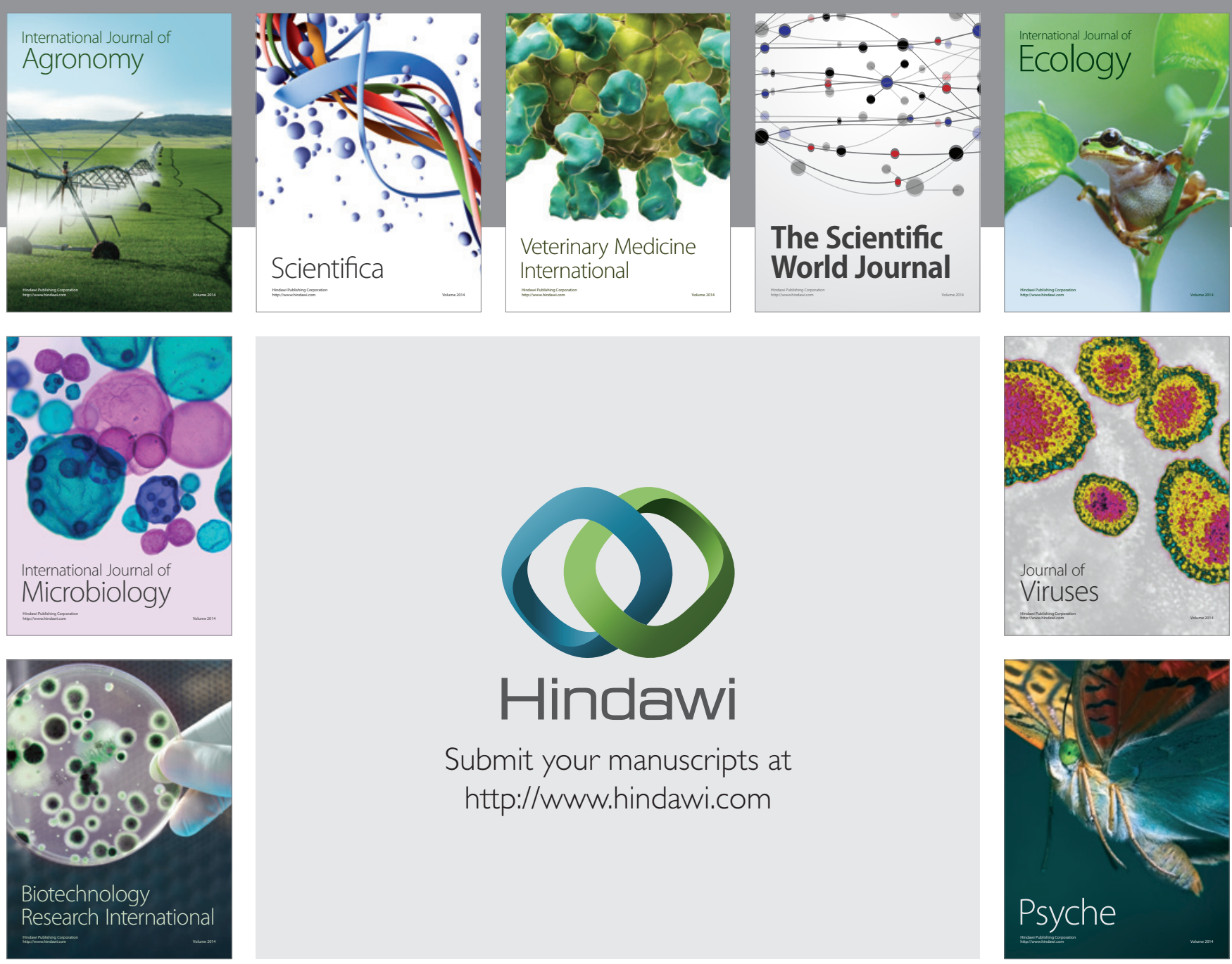

Submit your manuscripts at http://www.hindawi.com
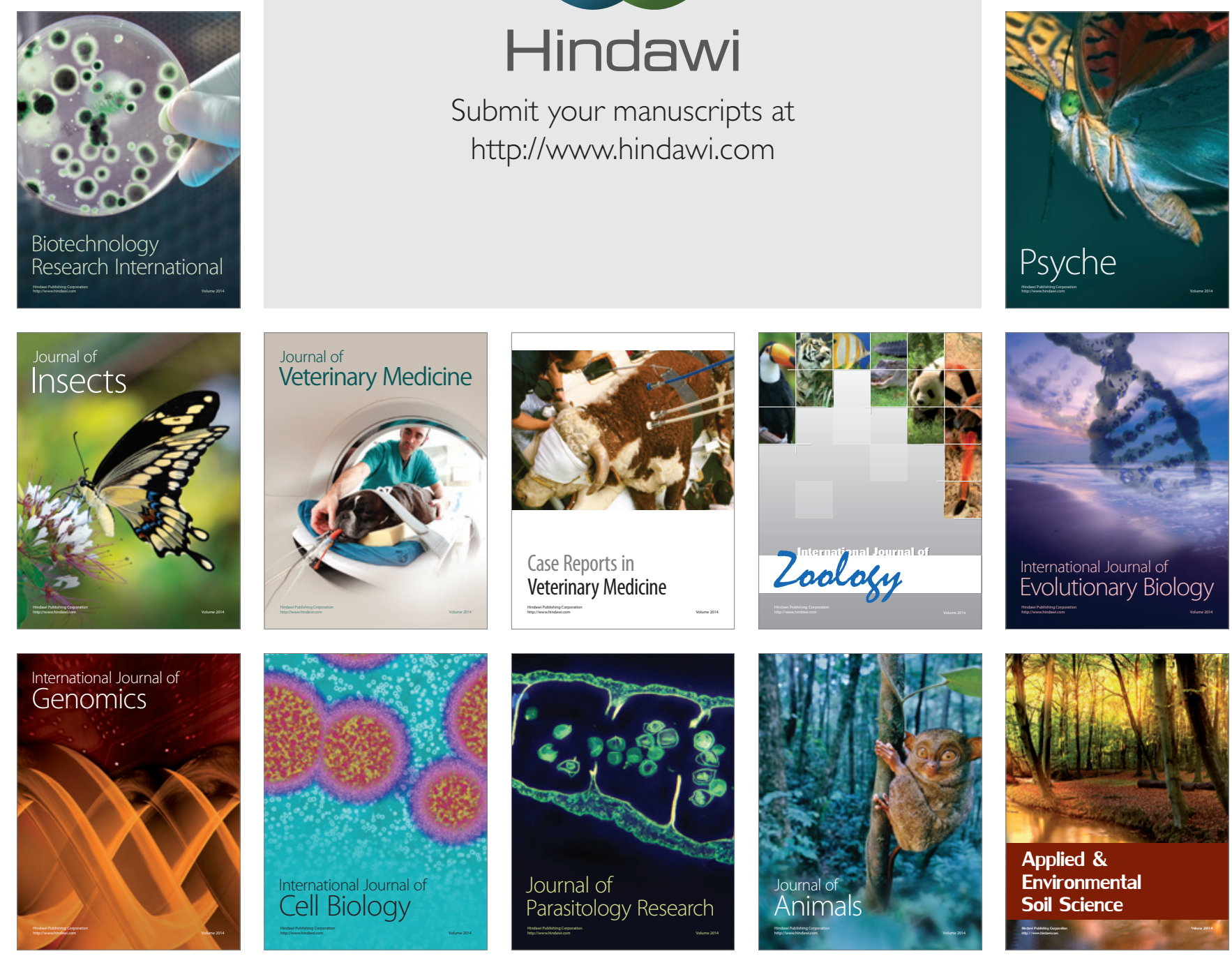